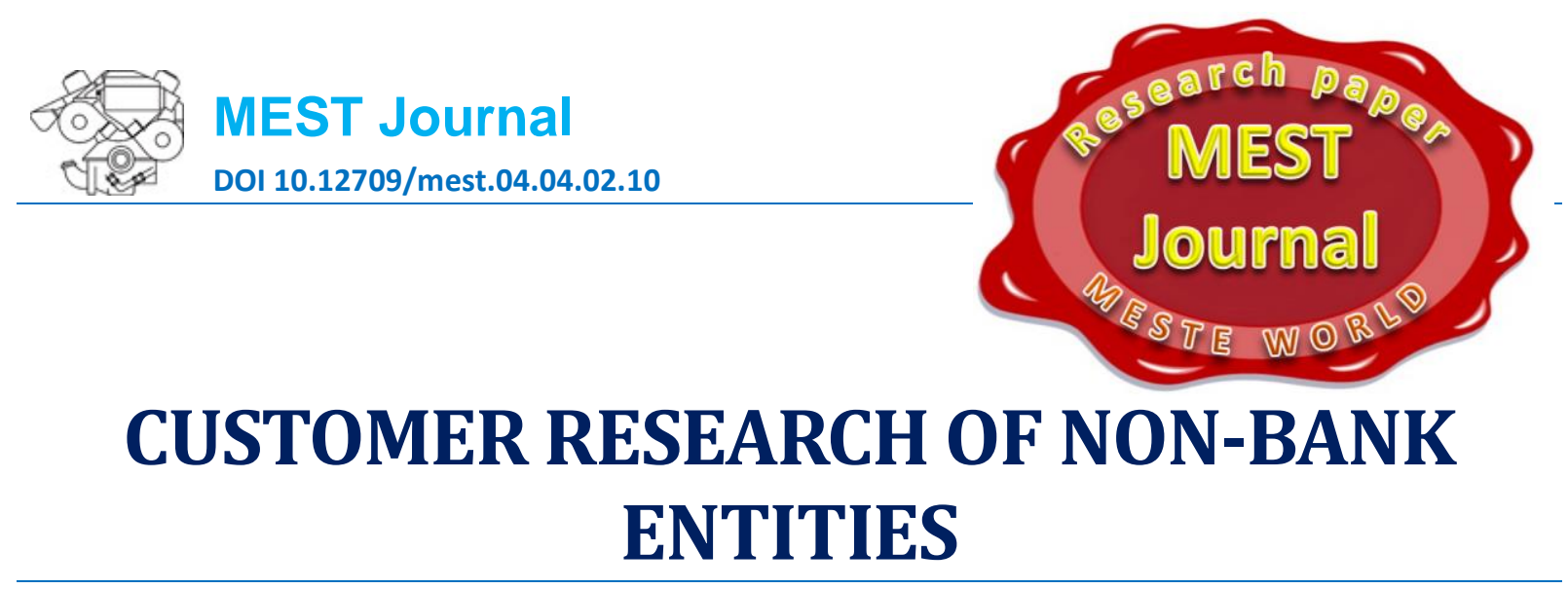

\title{
Lubica Filipova
}

Faculty of Economics and Business, Pan-European University, Bratislava, Slovak Republic

OMESTE

JEL Category: E44

\begin{abstract}
The issue of nonbank entities in the Slovak Republic and segmentation of their customers is extremely topical and important. Its topicality and importance is emphasized by increasing number of nonbank entities on financial market established by either legal or physical persons. Almost thirty thousand distraint cases annually when incomes and property of nonbank customers are seized for failure to repay raises attention on this topic, too. The legal environment in the Slovak Republic enables to establish nonbank entities. They are performed under Commercial Code and other laws regulating nonbank activities when acting as creditors providing consumer credits and loans to its customers. Therefore, the nonbank entities with their products and services are generating competitive landscape for bank sector. Customers are basic precondition for financial institution performance. All methods and forms of goaldirected marketing are used to address customer. To gain success the nonbank entities are forced to search for those groups of customers which will be interested in their products and services. They use a number of modern methods and research techniques for this purpose. The author points in the paper at the importance of segmentation of non-bank entities customers in the Slovak Republic. Theoretical starting points are followed by brief description of the evolution of non-bank entities in the Slovak Republic as well as by description of their legal framework. There are selected results of author's research on segmentation of non-bank entities customers in the Slovak Republic presented in the paper's core. Based on these results the author evaluates present situation of segmentation taking into consideration segmentation criteria, she identifies problem areas and suggests solutions for improvements.
\end{abstract}

Keywords: non-bank entity, customer, segmentation, marketing research

\section{INTRODUCTON}

The issue of non-bank entities in the Slovak Republic and segmentation of their customers is extremely topical and important.

Address of the author:

L'ubica Filipova

拝=゙ lubica.filipova@paneurouni.com
Its topicality and importance is emphasized by increasing number of non-bank entities on financial market established by either legal or physical persons. Almost thirty thousand distrait cases annually when incomes and property of non-bank customers are seized for failure to repay, raises attention on this topic, too.

The legal environment in the Slovak Republic enables to establish non-bank entities. They are 
performed under Commercial Code and other laws regulating non-bank activities when acting as creditors providing consumer credits and loans to its customers. Therefore the non-bank entities with their products and services are generating competitive landscape for bank sector.

Customers are basic precondition for financial institution performance. All methods and forms of goal directed marketing are used to address customer. To gain success the non-bank entities are forced to search for those groups of customers which will be interested in their products and services. They use a number of modern methods and research techniques for this purpose.

The paper is focused on this topic, especially on research of non-bank customers reflecting segmentation criteria.

\section{METHODOLOGY}

The aim of this paper is to identify and to evaluate present status of segmentation reflecting segmentation criteria and suggest solutions for improvements. A survey on segmentation of nonbank entities customers in the Slovak Republic was used for this purpose.

The first part of this paper is a compilation of theoretical starting points and description of nonbank entities and their progress in the Slovak Republic since 2009. After that a legal framework of non-bank entities is presented. To elaborate this part of the paper the author has sourced in insufficient national as well as in international bibliography, magazines and scientific and expert papers and applicable legal norms of the Slovak Republic and the European Central Bank, too.

The core of the paper is based on presentation of selected findings of author's research on segmentation of non-bank entities customers in the Slovak Republic using electronic questionnaires. Goal and hypothesis of the survey are based on theoretical information achieved during studies at the School of Economics and Management of Public Administration in Bratislava as well as own work experiences in some bank entities. Diagrams and descriptions of findings and current situation are used to present survey results.

Partial results describe positives and negatives of current situation. Therefore there is a part of this paper bringing also starting points for solutions to improve the situation in favour of non-bank entities and their customers. The third chapter is based on information gained from 362 survey respondents.

We have used standardised scientific methods as e.g. method of scientific abstraction and description especially when describing matters and features of the financial market in the Slovak Republic. Methods of scientific analysis, synthesis and comparison were used, too. Survey method and mathematic-statistical method, diagram method and method of scientific induction and deduction were applied to formulate findings and solutions in final part of the paper.

\section{THEORETICAL STARTING POINTS OF ANALYSED TOPIC}

Only definitions of terms related to analysed topic were chosen to describe theoretical starting points of segmentation of non-bank entities customers.

Market presents selling and buying processes between individual economic subjects on financial - economic basis. It is split up in market of goods and services, market of production capital, financial market, information market and ideology market. (Hrvolova, Nincakova, \& Vavrova, 2006, p. 17)

Financial market is a place where a variety of free financial means in form of savings of diverse economic subjects meets a demand of other economic subjects on these means using those as investments. The task of the financial market is to move financial means from subjects with their surplus towards subjects with their deficit. (Hrvol'ova, Nincakova, \& Vavrova, 2006, p. 17)

Bank marketing as a special task starts with marketing research specifying clients' needs and wishes. Findings of marketing research as well as results of evaluation of banks' macro and microclimate are basis to evaluate bank's position on banks' market, to audit goals and to define detailed operative aims. (Medved, et al., 2012, p. 489)

Financial marketing incorporates specific features which are distinguishing it from marketing in general, it can be understood as a marketing of services.

Customer's position within marketing concept is dominant. He /She decides if offered products will 
be accepted or not, i.e. or if product's have such impact on him/her that he/she is willing to provide required value, or if exchange or transaction will be carried out for provided advantage. (Medved, et al., 2012, p. 14)

The aim of marketing is to know customer and to understand him/her in the way the offered products will pass him/her and he/she will accept them and will require them to fulfil his/her demands. (Medved, et al., 2012, p. 14)

Segmentation of markets is described as an offensive strategy, coming out of market production and definition of new products in relation to demand's specification (Kita \& et al., 2010, p. 26).

How is current Slovak customer? Firstly, he/she is for a long time extremely prices sensitive, still rather conservative, relied on good experiences from the past, careful and in opposite to young generation he/she do not trust immediately newsflashes. (Kostal, 2005, p. 10)

Segmentation of the market is based on adequate proportioning of market into homogenate parts, so called market segments, which become target market of a company with specific. Segment can be defined as a part of a market, which is created by consumers with similar features, behaviour and purchasing decision on this market. (Medved, et al., 2012, p. 546) According to Cibakova (Cibakova, Rosza, \& Cibak, 2007, p. 56) market segment is built out of consumers with similar reactions on selected group of marketing's impulse.

Segmentation is a tool for separation of needs of customers using specific service or product. It divides market into smaller homogeny parts and enables quick response on changes in market demands. We deal with the segmentation intuitive (we can use own experiences) and systematic (focusing on competition). (Medved, et al., 2012, p. 547)

CRM is an information system gathering existing business applications back - office and new applications front - office. Customers' database is a product which value grows permanently with

1 Directive 2013/549/EC of the European Parliament and of the Council (EC 549/2013, intensive usage. (Jelinek, 2006, p. 3) The aim of $C R M$ is to build relations with customers beneficial for both parties - for an institution as well as for a customer (customers' loyalty, increase of customers' satisfaction, coordination of communication among particular units ...). (Koraus, 2011, p. 162)

Generally speaking, non-bank entities are legal or physical persons with no bank licence. According to Commercial Code their line of business is acceptation of deposits, providing of loans and consumers' credits, financial advisory, leasing and other financial services and operations etc.

The National Bank of Slovakia in concordance with particular legal norms of the EU ${ }^{1}$ classifies the non-bank entities into category Other financial agents except insurance corporations and pension funds with labelling S. 125.

All financial corporation and quasi corporation acting as financial agents on a basis of obligation acceptation in other forms than currency from other institutional units, financial institutions or insurance-technic reserves belong to this same group.

Non-bank entities acting on Slovak financial market could be defined as Financial corporations providing credits (Vighova \& Stangova, 2013, pp. 8-12), as e.g. financial agents providing leasing, instalment purchase and customers or business credits or factoring (a method of financing shortterm credits provided by products and services supplying). (NBS, 2015, pp. 29,35)

According to the methodology of the ECB into subsector S.125 belong e.g.:

- Exportno-importná banka SR (Export-import bank of the Slovak Republic),

- Tatra-leasing, s.r.o. (Tatra-leasing Ltd.)

- OTP Faktoring Slovensko, a.s., (OTP Factoring Slovakia Ltd.)

- Vokswagen Finančné služby Slovensko, s.r.o, (Volkswagen Financial Services Slovakia Ltd.)

- HomeCredit Leasing, a.s. (HomeCredit Leasing Inc.)

2013) and Directive 2013/1071 of the European Central Bank (ECB/2013/33, 2014) 
- The European Stability Mechanism (ESM) so called „permanent European rescue fund“.

We can divide the non-bank entities in the Slovak Republic according to the type of contract or according to the legal form of business.

According to the type of contract the non-bank entities can be divided into groups of entities using:

- contracts on silent partnership,

- agreements on forward action selling,

- loan agreements.

- note purchase,

- trust agreement on financial means.

According to the legal form of business the nonbank entities can be divided into groups taking into consideration the Commercial Code:

- physical person,

- limited liability company,

- company limited by shares,

- public trade company,

- limited partnership.

\section{EVOLUTION OF NON-BANK ENTITIES ON FINANCIAL MARKET OF THE SLOVAK REPUBLIC}

Non-bank entities exist on financial market in the Slovak Republic since 2009.

At the beginning they were in an operation and they accepted more contribution than they had to pay out (Openiazoch, 2016). It was called pyramids (or Ponzi) schema. Such type of structure has to be supported by more and more new investors.

Non-bank entities explained through expensive and convincing advertising the extraordinary interests by various money-making activities such as keeping hockshops, betting agencies, leasing business, commodity exchange dealing etc. None of mentioned activities could bring confirmed acquisition few times higher than ordinary interests' rate (Kabat \& Filip, 2015, pp. 170-176). And in case they did, these companies could gain necessary capital cheaper than thirty per cent which they offered to their clients.

Non-bank entities were not obliged to inform about basic information regarding financial situation or business plans.

Three well-known non-bank entities Horizont Slovakia o.c.p., Ltd.., AGW, Ltd. a BMG Invest, Ltd. are an example of misusing the legal environment in the Slovak Republic

These companies promised in their expensive advertising activities unrealistic interests. A comparison of interests' rate promised in 1997 2001 with actual interests' rate of banks in the Slovak Republic. A huge difference can be observed there.

Table 1 Comparison of interests' rate promised by non-bank entities in the Slovak Republic in 1997 2001 and actual interests' rate of banks in Slovakia, dated 29 March 2016

\begin{tabular}{|c|c|c|c|c|c|c|c|c|}
\hline \multirow{2}{*}{$\begin{array}{l}\text { Maturity } \\
\text { (in months) }\end{array}$} & \multicolumn{2}{|c|}{$\begin{array}{l}\text { Promised interests } \\
\text { of contributions in } \\
\text { percentage }\end{array}$} & \multicolumn{6}{|c|}{$\begin{array}{l}\text { Actual interests rate of selected banks in the Slovak Republic } \\
\text { to date June } 30,2015\end{array}$} \\
\hline & $\begin{array}{l}\text { BMG } \\
\text { Horizont }\end{array}$ & AGW & $\begin{array}{c}\text { BKS } \\
\text { Bank } \\
\text { AG }\end{array}$ & ČsOB & $\begin{array}{l}\mathrm{J} \& \mathrm{~T} \\
\text { Banka }\end{array}$ & $\begin{array}{l}\text { Privat } \\
\text { banka }\end{array}$ & $\begin{array}{l}\text { Slovenska } \\
\text { sporitel'na }\end{array}$ & Tatrabanka \\
\hline 3 & 22.00 & 22.00 & 0.60 & 0.20 & - & 0.80 & 0.05 & 0.05 \\
\hline 6 & 25.50 & 27.50 & 0.70 & 0.40 & - & 1.00 & 0.10 & 0.05 \\
\hline 9 & 31.00 & 29.50 & - & - & - & & - & - \\
\hline 12 & 35.00 & 34.50 & 1.15 & 1.40 & 1.60 & 1.50 & $0.30-2.50$ & 0.15 \\
\hline 24 & 37.00 & 35.50 & 1.15 & 1.5 & 1.60 & 1.70 & $0.40-0.90$ & 0.20 \\
\hline 36 & 39.50 & - & 1.15 & 1.6 & 2.00 & 1.75 & $0.50-1.00$ & 0.25 \\
\hline
\end{tabular}

Source: own comparison according to http://banky.sk/terminovane-vklady/, on-line 29 March,2016

These companies spent enormous financial means for deceptive advertising comparing to banks. For example, Horizont Slovakia, Ltd. spent since 1997 till 20011.34 billion Slovak crowns. 
BMG Invest spent 812 million Slovak crowns and AGW 321.13 million Slovak crowns for advertising. (banky.sk, 2016)

Although the National Bank of Slovakia published in September 1998 a notice to inform public about breaking law on banks /dated 1992/ by mentioned non-bank entities, the citizens intended to earn the most had taken the risk. Losses were enormous. For example, the customers of Horizont Slovakia and BMG Invest gained in 1997 - 2001 more than two billion Slovak crowns from citizens and agreed on 856,000 contracts. Despite the fact they have paid more than 1.75 billion Slovak crowns for contribution, there are more than 170,000 persons with no recovery of claims.

Based on these examples the government and members of parliament have adopted legal norms with the aim to stop the non-bank entities' dishonest acting and to protect customers citizens of the Slovak Republic.

Slovak courts have condemned proprietors of non-bank entities but fooled clients were paid minimum sums as a part of companies' liquidation.

\section{LEGAL FRAMEWORK FOR NON- BANK ENTITIES}

Since 2010 and in accordance with legal norms of the EÚ, the Slovak Republic and the ECB the loans activity of non-bank entities is regulated by National Bank of Slovakia.

The first act determining rules for credit activities of bank and non-bank entities in the Slovak Republic was act of the National Council of the Slovak Republic No. 129/2010 Coll. on consumers' credits and other credits and loans for consumers and on changes and amendments of some other acts of 9 March 2010.

This act is a total transposition of Directive 2008/48/EC of the European Parliament and of the Council of 23 April 2008 on credit agreements for consumers and repealing Council Directive $87 / 102 /$ EEC (hereinafter referred as "directive") into the Slovak legal system.

It arranges rights and obligations related to provision of consumer's credit based on consumers' credit agreement, conditions to provide consumer's credit, terms of consumer's credit agreement, way of counting total costs of a consumer related to the provision of consumer's credit, conditions to be fulfilled if requiring admittance to provide consumers' credits, conditions to execute creditor's activities and other measures of consumer's protection.

Non-bank entities are considered as a creditor, (§2, letter b. Act No.129/2010 Coll. of 9 March 2010) acting as a physical or a legal person who offers or provides consumer's credit as a part of its business activities. The act describes detailed steps and information needed before the consumer's credit agreement is signed especially on advertising, on provided information, on the obligation to check the consumer's ability to pay the credit. It specifies conditions to access databases, mandate the National Bank of Slovakia to establish on its website a list of creditors (a register), it determines terms of consumer's credit agreement. Then it describes a calculation of the annual percentage rate of charge and conditions to gain permission of the National Bank of Slovakia to provide consumer credits.

Latest amendments of the act of the National Council of the Slovak Republic No. 129/2010 Coll. is the act of the National Council of the Slovak Republic No. 35/2015 Coll. This act adds some important clauses regarding non-bank entities. The Ministry of Finance of the Slovak Republic expects that the new act will force dishonest business entities to leave the financial market.

The act describes detailed the steps leading to transparency and increase of audit on the market of consumers' credits providers. Two meritorious changes have been implemented:

- implementation of licence procedure for creditors,

- implementation of obligation to check information in consumers' credits register due to evaluate the ability of a consumer to pay for consumer's credit and other costs related to the consumer's credit.

According to this amending act the non-bank entities are supervised by the National Bank of Slovakia and can act just with a licence (NBS, §20 Act of the National Council of the Slovak Republic No. 35/2015 Coll). Conditions to be fulfilled when requiring a licence:

- legal form of a company limited by shares or a company with limited liability,

- establishment of supervisory board, 
- basic equity of at least 500000 Euro paid as a contribution,

- transparent and trustful origin of paid contribution in basic capital,

- professional competence, integrity and trustfulness of physical person nominated at the position of statutory authority member, or manager, member of supervisory board, or chief of the intern audit unit of an applicant,

- appropriateness of legal person,

- presentation of a system to check availability of clients to pay for credits and a system to provide clients with credits including methods to solve problems and claims,

- transparency of a group and its close connections,

- legal norms and their enforcement, close connections do not obstruct the execution of supervisory,

- location of a seat or its organisational unit at the territory of the Slovak Republic,

- formulated claiming order.

Present credits providers could act according to current evidence in the creditors' database until 31 August 2015 (NBS, §20 Act of the National Council of the Slovak Republic No. 35/2015 Coll, 2015). Then the databases have expired. They can send an application to the National Bank of Slovakia to ask for a permission to provide consumers' credits with or without limitation or to provide other credits or loans. The National Bank of Slovakia offers example of application's letters on its website:

- application letter on permission to provide consumers' credits without limitations, or with limitation (legal person) and with limitation (physical person),

- application letter on permission to provide credits and loans to consumer.

Then there are other forms (annexes of the application letter) that can be downloaded from the website: declaration on oath of the person nominated as a member of statutory board, applicant - physical person - declaration on trustfulness and legal person - on competency.

The National Bank of Slovakia has a new database of creditors with valid permission to provide or to offer consumers' credits since 31 August 2015. Only twenty-three non-bank entities were registered in the database by 28 March 2016 (NBS, Nebankovi veritelia a ostatne subjekty ,
2016). Comparing to 31 August 2015 (250 registered entities) it is a decrease by 277 subjects.

In this connection some information on the establishment of black or shadow financial market in the Slovak Republic occurs. It is a concurrency to legal subjects. Clients of such subjects have to face enormous risk of property deprivation in case of insolvency, if not able to pay for a credit with inadequate interests.

\section{RESEARCH ON SEGMENTATION OF NON-BANK ENTITIES CUSTOMERS}

A questionnaire via internet has been used to gain information on current status regarding the segmentation of non-bank entities customers in the Slovak Republic. Its goal was to identify the opinions of non-bank entities customers on quality of services provided by the non-bank entities.

Main hypothesis of the research was based on the idea that the segmentation of non-bank entities customers is influenced by the relationship towards the product and the quality evaluation of provided products and services.

Electronic questionnaire has been worked out with the software accessible on iAnkety.sk website. It has contained six questions to identify a respondent and other twenty-five closed questions to gain main information on segmentation criteria:

- geographic criteria - the Slovak Republic, region, city/municipality,

- demographic criteria - gender, age, education, occupation, social status, income,

- psychologic criteria - social class, life style, personality, quality evaluation,

- clients' behaviour, their relationship towards products - expected apport, chance, attitude towards product, devotion to the non-bank entity, variety of information, frequency of products ' usage.

Data collection via electronic questionnaire was realised on public accessible internet (VSEMVS, 2015) during four months. Totally more than 400 questionnaires were answered in this time period. Then they have been checked and 362 completed questionnaires were chosen for statistics. The respondents are from all regions of the Slovak Republic. 
Due to limited extent of this paper the author has chosen only some interesting results for presentation.

Based on the research results, it can be stated that, following a demographics criterion, a segment of non-bank entities customers consists mainly of clients aged 26-45 (45 per cent), families with no or one child (50 per cent), with total income of the family $301-600 € /$ month (39 per cent).

In context of psychologic criteria, the majority of clients belongs to lower or lower middle class, no one to upper class $(75 \%)$.

According to the results of customers, segmentation's research regarding the relationship of a non-bank entity towards its clients comes out that the majority of clients are satisfied $(53 \%)$, positively evaluating promptness $(23 \%)$, administrative modesty (15\%) and processes without checking income and property guarantee (14\%). The most of clients evaluates positively the information on credits terms and are loyal towards their non-bank entity. Almost $70 \%$ of respondents would welcome customers' centres of non-bank entities to help with problems or to pay cash for credit's instalment.

Not many clients were not able to repay the credits and their incomes and property were distraint. These are clients with no insurance against insolvency.

Very important is the finding that the customers were satisfied with the credits because they reached their purpose.

There were twelve questions chosen to check the main hypothesis. Based on the results it can be stated that the main research hypothesis is confirmed. The clients have clearly declared in their answers and evaluations that deciding influence on customers' segmentation is based on the relation of the customer towards product and non-bank entity towards customer.

\section{SUGGESTIONS}

The author has worked out some suggestions of improvement measures because the research findings have revealed weak sites of current status. The suggestions of measures are concentrated as on the non-bank entity as well as on customer.
Regarding the non-bank entities, the suggested measures are related to products or service features, to contact of non-bank entity with customers, to professional and psychologic education of non-bank entity employees, image and distribution improvement.

Suggested measures regarding the customer are: to choose licenced non-bank entity, with real seat and customer services, to focus on an annual percentage of costs. Those with 30 per cent rate and more are highly risk (Kovac \& Hudakova, 2015). The customer should be informed about sanctions and penalties for late payment. If necessary to search for solutions of problems with an agreement or with a court.

A general suggestion can be presented, too. The establishment and the activities of non-bank entities should be regulated by law as it is in case of banks in the Slovak Republic.

\section{CONCLUSIONS}

At the end it can be stated that the segmentation of customers of non-bank entities on financial market in the Slovak Republic is an actual and important issue as well as for professionals as for general public including their customers.

The paper has presented the most important theoretical information of mentioned topic, has described the evolution of non-bank entities and has characterized legal framework of operation and functioning of non-bank entities. Based on this it has prepared a suitable framework to research of segmentation by customers.

The most beneficial part of the paper is the presentation of research findings collected via internet from real customers of non-bank entities from all regions in Slovakia. The results have proved the hypothesis of the research: the segmentation of customers is influenced mainly by a product and by a relationship of non-bank entity towards its customer.

Positive on current situation regarding the nonbank entities in the Slovak Republic is the fact that by adoption of law the condition to grant permission to advance loans and credits are made more restrictive. The customer has the possibility to check the credibility and reliability of entities via website of the National Bank of Slovakia. It is up to him/her if he/she make use of this service or will choose risk subjects on a black market. 


\section{WORKS CITED}

§2, letter b. Act No.129/2010 Coll. of 9 March 2010. (2010, Mar 09). Retrieved from NBS: http://www.nbs.sk/_img/Documents/_Legislativa/_BasicActs/A129-2010.pdf

banky.sk. (2016, Mar 25). http://banky.sk/zoznam-bank-na-slovensku/. Retrieved from banky.sk: www.banky.sk

Cibakova, V., Rosza, Z., \& Cibak, L. (2007). Marketing služieb. Bratislava: lura Editionspol. s.r.o.

EC 549/2013. (2013). Regulation (EU) No 549/2013 of the European Parliament and of the Council of 21 May 2013. Official Journal of the European Union, 174/1-727.

ECB/2013/33. (2014, Dec 16). Regulation (EU) No 1071/2013 of the European Central Bank of 24 September 2013. Official Journal of the European Union, 297/1-50. Retrieved from http://eurlex.europa.eu/legal-content/en/TXT/PDF/?uri=CELEX:32013R1071\&from=EN

Hrvol'ova, B., Nincakova, L., \& Vavrova, K. (2006). Analyza financnych trhov. Sprint.

Jelinek, J. (2006). Jak inteligentne vyuzit CRM system. Trend marketing, 3(12).

Kabat, L., \& Filip, S. (2015, Jan 15). Alternative possibilities of detection of manipulation with the accounting data. (Z. Čekerevac, Ed.) MEST Journal, 3(1), 170-176. doi:10.12709/mest.03.03.01.18

Kita, J., \& et al. (2010). Marketing. Bratislava: Iura Edition.

Koraus, A. (2011). Financny marketing. Bratislava: Sprint.

Kostal, D. (2005). Zakaznika ziskate komunikaciou. Obchod, 10(3), 10.

Kovac, M., \& Hudakova, M. (2015). Možnosti merania bezpečnosti občanov v podmienkach územných celkov SR. Praha: WoltersKluwer.

Medved, J., Sobek, O., Sipko, J., Dufala, V., Demjan, V., Kosik, O., . . Vargova, V. (2012). Banky teoria a prax. Sprint dva.

NBS. (2015, Apr 01). §20 Act of the National Council of the Slovak Republic No. 35/2015 Coll. Retrieved from NBS.

NBS. (2015). Metodicka prirucka pre zatried'ovanie poloziek aktiv a pasiv podla sektora zmluvnej protistrany. Menova a financna statistika 2015. Bratislava: Narodna banka Slovenska.

NBS. (2016). Nebankovi veritelia a ostatne subjekty . Retrieved from Narodna Banka Slovenska: http://www.nbs.sk/sk/dohlad-nad-financnym-trhom-prakticke-informacie/zoznamy-subjektovregistre-a-formulare/zoznamy-subjektov/veritelia

Openiazoch. (2016, May 05). Nebankove institucie ako nastroj na ukladanie penazi. Retrieved from Financne centrum O peniazoch: http://openiazoch.zoznam.sk/nebankove-spolocnosti/vklady

Vighova, A., \& Stangova, N. (2013). Information System - Basis for Successful Management of the Organization. International JournalofAdvances in Management and Economics, 8-12.

VSEMVS. (2015). Dotazník "Segmentacia zakaznikov nebankovych subjektov". Retrieved from iankety.sk: http://www.iankety.sk/dotaznik/355446624/

Received for publication: $\quad 09.04 .2016$

Revision received: $\quad 24.05 .2016$

Accepted for publication: $\quad 10.06 .2016$ 


\section{How to cite this article?}

Style - APA Sixth Edition:

Filipova, L'. (2016, July 15). Customer research of non-bank entities. (Z. Čekerevac, Ed.) MEST Journal, 4(2), 94-102. doi:10.12709/mest.04.04.02.10

Style - Chicago Sixteenth Edition:

Filipova, L'ubica. 2016. "Customer research of non-bank entities." Edited by Zoran Čekerevac. MEST Journal (MESTE) 4 (2): 94-102. doi:10.12709/mest.04.04.02.10.

Style - GOST Name Sort:

Filipova L'ubica Customer research of non-bank entities [Journal] // MEST Journal / ed. Čekerevac Zoran. - Belgrade : MESTE, July 15, 2016. - 2 : Vol. 4. - pp. 94-102.

Style - Harvard Anglia:

Filipova, L., 2016. Customer research of non-bank entities. MEST Journal, 15 July, 4(2), pp. 94-102.

Style - ISO 690 Numerical Reference:

Customer research of non-bank entities. Filipova, L'ubica. [ed.] Zoran Čekerevac. 2, Belgrade: MESTE, July 15, 2016, MEST Journal, Vol. 4, pp. 94-102. 